\title{
The Role of Servant Leadership and Work Motivation on Organizational Citizenship Behavior: Evidence from Indonesian Generation Y Employees
}

\author{
Indra Wahyu ${ }^{1}$, Anoesyirwan Moeins ${ }^{2}$, Widodo Sunaryo ${ }^{3}$ \\ ${ }^{1,2,3}$ Pakuan University, Indonesia
}

\begin{abstract}
The purpose of this study is to find an effort to increase organizational citizenship behavior of Generation Y employees through the identification of the influence of servant leadership and work motivation. This research was conducted on Generation Y employees are governmental officers aged 23 - 43 years at Bogor Regency. The research sample was 86 persons of generation Y from 3 agencies and 11 offices at Bogor Regency. This research uses a quantitative approach and is completed by a qualitative approach through the Delphi technique. The findings revealed that servant leadership has a significant and positive effect on $O C B$ of generation $Y$, work motivation has a significant and positive effect on $O C B$ of generation $Y$, servant leadership and work motivation has a significant and positive effect on $O C B$ of generation $Y$. The results of quantitative and qualitative research conclude that the improvement of the organizational citizenship behavior (OCB) of Generation Y employees can be done through strengthening servant leadership and work motivation.
\end{abstract}

Keywords: Generation Y, organizational citizenship behavior (OCB), servant leadership, work motivation.

\section{INTRODUCTION}

Agencies and Services in Bogor Regency are government organizations working in the public service sector. One way to improve the quality of public services is by increasing the Organizational Citizenship Behavior (OCB) behavior of Generation Y employees. The research gap from this study is based on data from the Central Statistics Agency (BPS) in 2018, that the HDI (Human Development Index) value of Bogor Regency namely 69.13, which is still low compared to the average HDI value for districts/cities in West Java of 71.30 (ranked 15th of 27) and the District / City HDI value in Indonesian territory of 71.39 (ranked 205th of 514), and based on Bogor Regency Government Performance Report / LAKIP 2019 data, that of the 23 performance indicators, 14 indicators $(60.9 \%)$ have been achieved and 9 indicators $(39.1 \%)$ have not been achieved.

Based on this, a preliminary survey was conducted to see the quality of public services from OCB behavior of Generation Y employees. The results of the preliminary survey found that $31 \%$ of Gen Y employees had problems with voluntary actions, $40 \%$ of Gen Y employees had problems with obeying rules, $53 \%$ of Gen Y Employees Y has problems with tolerance, $34 \%$ of Gen Y employees have problems with work ethics, $42 \%$ of Gen Y employees have problems with moral obligations, $60 \%$ of Gen Y employees have problems with initiative attitudes, and $46 \%$ of Gen Y employees have problems with personal development. This study is to find efforts to improve OCB by identifying the influence and differences of servant leadership and work motivation on OCB of Generation Y employees in Bogor Regency.

\section{LITERATURE REVIEW AND HYPOTHESIS DEVELOPMENT}

\section{Generation Y}

Generation Y known as Net Generation or Millennials is the generation born in 1977-1997. Influencing Generation $\mathrm{Y}$ is the rise of computers, the internet, and other digital technologies. Bencsik \& Machova (2016) divide Generation Y's behavior into several factors, namely the view that is centered on egoism and the short term, relationships are virtual networks and work networks, work goals are trying to get a position as leadership and promotion, utilizing IT technology, and having values such as flexibility, mobility, broad but superficial knowledge, success orientation, creativity, and freedom of information are priorities. 


\section{Organizational Citizenship Behavior (OCB)}

Luthans (2011) argues that OCB is the characteristics or traits, certain personalities contained in individuals, namely cooperative traits, likes to help and care for others and sincerity to work. According to Colquitt et al. (2014) OCB is the voluntary behavior of individuals who are not affected by the reward system for contributions to the organization, while Gibson et al. (1991) OCB is the behavior of individuals to do work outside their assigned work effectively and efficiently without considering rewards or bonus, but it supports organizational value. Podsakoff et al. (2000) stated that OCB can affect organizational effectiveness because it helps increase coworker productivity, managerial productivity, efficient organizational resources, the stability of organizational performance and adapts to changes in its business environment. From the opinion of Colquitt et al. (2014), Gibson et al. (1991), Luthans (2011), and Podsakoff et al. (2000) can summarize that there are several dimensions of OCB, namely altruism is the behavior of helping colleagues in completing work in unusual situations, without coercion from other parties, conscientiousness is the behavior of carrying out tasks and responsibilities exceeding the expected minimum standards, sportsmanship is behavior that describes sportsmanship and tolerance towards the organization, shown by looking at positive aspects of the organization compared to negative aspects, Courtesy is behavior that alleviates problems with work faced by colleagues, civic virtue is behavior that describes support for administrative functions, individual initiative is behavior developing a way of working that is better than today and the implementation of tasks that are more than the set standards and self-development is the behavior of increasing personal competence and following the latest developments.

\section{Servant Leadership}

Robbins \& Judge (2017) define servant leadership as a leadership style that is characterized by going beyond the leader's interests and will focus on opportunities to help followers grow and develop. According to Spears (2010) servant leadership is a leader who prioritizes service, starting with the natural feeling of someone who wants to serve and to put service first. Meanwhile, Barbuto Jr et al. (2014) servant leadership is leadership that has a natural desire to serve others. From the opinion of Barbuto Jr et al. (2014), Robbins \& Judge (2017), and Spears (2010) can be summarized there are several dimensions of serving leadership, namely listening is a leader who listens attentively to others, without coercion from other parties, Empathy is a leader who tries to understand colleagues and can empathize with others, Healing is a leader who can create emotional healing and relationships himself or relationships with others, Awareness is a leader who is aware of understanding issues involving ethics, power, and values, Persuasion is a leader who serves trying to convince others rather than forcing obedience, Conceptualization is a leader who can see the problem from a conceptualization point of view and Stewardship is a leader who emphasizes openness and persuasion to build trust from others. Research by Al-Amri et al. (2016) concluded that servant leadership has a significant and positive influence on the OCB of employee with F count $=13.165>$ F table and Sig. $<0.05$.

\section{Work Motivation}

Robbins \& Judge (2019) define motivation as a process that explains the strength, direction, and persistence of a person to achieve goals. Luthans (2011) motivation is a process that begins with physiological or psychological deficiencies that drive behaviors or drives aimed at goals and incentives. Meanwhile, Griffin \& Moorhead (2014) stated that motivation is a series of forces that cause people to behave in certain ways. From the opinion of Griffin \& Moorhead (2014), Luthans (2011), and Robbins \& Judge (2019) can be summarized that there are 2 (two) factors of motivation, namely the intrinsic factor which consists of the drive for self-achievement and reward for work performance, and extrinsic factors which consist of salary and other benefits, hierarchical level, promotion, work environment, and co-workers. Research by Shaaban (2018) concludes that intrinsic work motivation has a significant and positive effect on Employee OCB of t count $=6.175>\mathrm{t}$ table and Sig. $<0.05$, and extrinsic work motivation has a significant and positive effect on employee OCB of $t$ count $=9.620>t$ table and Sig. $<0.05$.

\section{The Effect of Servant Leadership on Organization Citizenship Behavior (OCB)}

A servant leader is a first servant who has a responsibility to contribute to the welfare of society and the community. Servant leadership looks at the needs of the people and asks himself how it can help them to solve problems and improve personal development. Servant leadership places the main focus on people because 
people are motivated to achieve their targets and to meet the expectations set (Musakabe \& Marganingsih, 2004). According to Chughtai (2008), the effective organizational function requires employees who not only perform roles determined by people but also participate in behaviors that go beyond formal obligations. This aspect of performance is consistent with the OCB concept introduced by Organ. OCB is free or wise behavior in the workplace that goes beyond the required basic job of a person. A servant leadership leader usually takes action that serves voluntarily. This action, among others, is due to helping and contributing to their subordinates in the form of teaching, love, experience, or advice. The behavior reflected in the servant leader greatly influences the OCB of its followers, because followers tend to imitate what the leader does. Research conducted by Vondey (2010) on 130 people who work in various industries throughout the United States shows that servant leadership is related to OCB. Therefore, It can be concluded that if the servant leaders have the soul to serve followers with sincerity and provide good examples of OCB, then this can also foster OCB in their employees. From this description, the following hypothesis can be taken:

\section{H1. Servant leadership has a significant effect on Organization Citizenship Behavior (OCB).}

\section{The Influence of Work Motivation on Organization Citizenship Behavior (OCB)}

The effect of work motivation on employee OCB has been widely studied before. Research conducted by Oren et al. (2013) found a positive relationship between work motivation and organizational citizenship behavior. The results of the study are following research conducted by Dewayanto (2016), which found an influence between work motivation and organizational citizenship behavior. The results of the study are following Moradi (2015) research that people who have inner strength for satisfaction based on achievement in self-concept are more likely to show actions of organizational citizenship behavior. The results of the study are following the research conducted by Penggalih \& Zulaicha (2013), the research shows that work motivation variables have a significant and positive influence on organizational citizenship behavior. the higher the motivation, the higher the organizational citizenship behavior. Based on this explanation, the following research hypothesis can be formulated.

\section{H2: Work motivation has a significant effect on organizational citizenship behavior (OCB).}

\section{Effect of Servant Leadership and Work Motivation on Organization Citizenship Behavior (OCB)}

The effect of servant leadershipand work motivation together has been studied by several previous researchers. Among them are Ragil \& Solovida (2020) who found facts on research conducted on employees of one of the local government-owned banks in Indonesia. Ragil \& Solovida (2020) conclusively concluded that the variable servant leadership and work motivation had a positive and significant effect on organizational citizenship behavior of Bank employees. The research above is in line with the conclusions of Maduningtias (2017) research which states that servant leadership and work motivation together have a significant effect on organizational citizenship behavior (OCB) in employees of a private service company in Indonesia. Based on this explanation, the following research hypothesis can be formulated:

H3: Servant leadership and work motivation have a significant effect on organizational citizenship behavior $(O C B)$.

\section{Population and Sample}

\section{RESEARCH METHOD}

The research was conducted from August 2019 to July 2020 in Bogor Regency, West Java Province, Indonesia. The study population was 110 Generation Y employees from permanent state civil servants from 3 agencies and 11 agencies in Bogor Regency. The research sample of 86 Generation Y employees was taken from the population calculated by the Slovin formula with a margin of error of $5 \%$.

\section{Framework}

Based on the hypothesis, the formulation of a framework of thought can be explained below: 


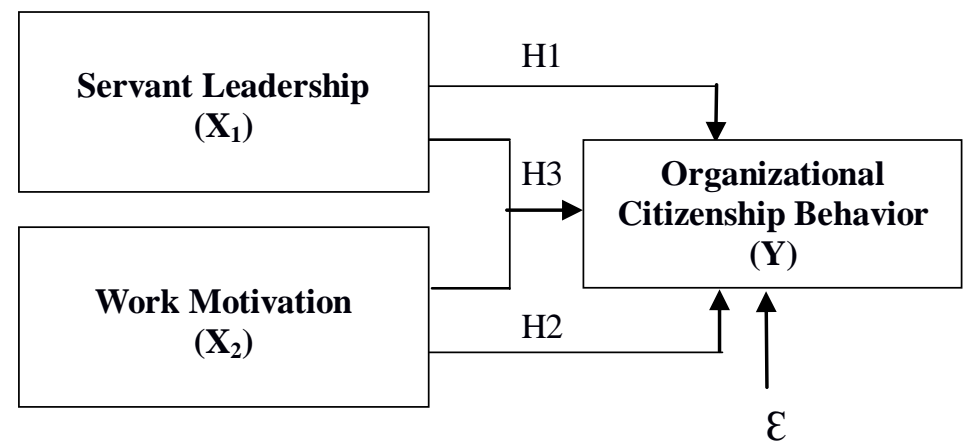

Figure 1. Research Framework

\section{Data Collection and Analysis}

The research was conducted quantitatively and qualitatively usmy a questionnaire. The quantitative stage is carried out as follows: 1) Validity Test with the Pearson Product Moment Correlation formula and Reliability Test with Alpha Cronbach formula, 2) Liliefors Normality Test, 3) Bartlett Homogeneity Test, 4) Linearity and Significance Test of Regression Equations, and 4) Hypothesis Test (Sugiyono, 2013). For the qualitative stage, the Delphi technique was carried out in the form of group conclusions and triangulation, then the qualitative results were compared with the quantitative results.

\section{RESULTS AND DISCUSSION}

Validity and Reliability Test

Table 1. Reliability Coefficient of the Questionnaire

\begin{tabular}{clccc}
\hline No. & \multicolumn{1}{c}{ Questionnaire Measurement } & Item & Validity & Reliability \\
\hline 1 & Organizational Citizenship Behavior & 34 & $\mathrm{r}>0.254$ & 0.907 \\
2 & Servant Leadership & 34 & $\mathrm{r}>0.254$ & 0.904 \\
3 & Work motivation & 34 & $\mathrm{r}>0.254$ & 0.893 \\
\hline
\end{tabular}

Obtained 34 items from 42 questionnaire items that are valid and reliable

\section{Normality Test}

Table 2. Results of Generation Y Employee Normality

\begin{tabular}{clccc}
\hline No. & Description & OCB & Servant Leadership & $\begin{array}{c}\text { Motivation } \\
\text { Work }\end{array}$ \\
\hline 1 & Empirical Data & 0.0947 & 0.0914 & 0.0643 \\
2 & Liliefors Standard & 0.0956 & 0.0956 & 0.0956 \\
3 & Result & Empirical <Standard & Empirical < Standard & Empirical <Standard \\
\hline
\end{tabular}

Conclusion: Data from the OCB questionnaire, serving leadership, and employee work motivation of Generation Y come from populations that are normally distributed.

Bartlett Homogeneity Test

Table 3. Results of Generation Y Employee Homogeneity

\begin{tabular}{clcc} 
No. & Description & $\begin{array}{c}\text { OCB above } \\
\text { Servant Leadership }\end{array}$ & $\begin{array}{c}\text { OCB above } \\
\text { Work motivation }\end{array}$ \\
\hline 1 & Empirical Data & 0.847 & 0.701 \\
2 & Sig value. & 0.05 & 0.05 \\
3 & Result & Empirical $>$ Sig. & Empirical $>$ Sig. \\
\hline
\end{tabular}

Conclusion: Data from the OCB questionnaire, serving leadership, and employee work motivation of Generation Y come from a population that is homogeneously distributed. 


\section{Linearity Test and Significance of Regression Equations}

Table 4. Linearity Test Results and Significance of Regression Equations Generation Y employees

\begin{tabular}{clcc}
\hline No. & Description & Servant Leadership with OCB & $\begin{array}{c}\text { Work Motivation } \\
\text { with OCB }\end{array}$ \\
\hline 1 & F count & 0.690 & 1,860 \\
2 & F table & 3.11 & 3.11 \\
3 & Empirical Data & 0.876 & 0.053 \\
4 & Sig value. & 0.05 & 0.05 \\
5 & Result & F count $<$ F table & F count $<$ F table \\
& & Empirical Data $>$ Sig. & Empirical Data $>$ Sig. \\
\hline
\end{tabular}

Conclusion: The relationship between servant leadership and OCB and the relationship between work motivation and OCB of Generation Y is linear and significant.

\section{Hypothesis Test Results}

Table 5. Hypothesis Test Results

\begin{tabular}{|c|c|c|}
\hline No. & Variables / Dimensions & Conclusion Test \\
\hline 1 & Servant leadership on OCB & $\begin{array}{l}\mathrm{t} \text { count }(4,394)>\mathrm{t} \text { table, Sig. }<0.05 \text {, with the regression equation: } \\
\mathrm{Y}=82.785+0.419 \mathrm{X} 1 \\
\text { Ho is rejected, } \mathrm{H} 1 \text { is accepted. } \\
\text { There is a significant and positive influence of servant } \\
\text { leadership on the OCB of Generation Y employees }\end{array}$ \\
\hline 2 & Work motivation on OCB & $\begin{array}{l}\text { t count }(8,862)>t \text { table, Sig. }<0.05 \text {, with the regression equation: } \\
\mathrm{Y}=48.961+0.662 \mathrm{X} 2 \\
\text { Ho is rejected, } \mathrm{H} 2 \text { is accepted. } \\
\text { There is a significant and positive influence of work motivation } \\
\text { on the OCB of Generation Y employees }\end{array}$ \\
\hline 3 & $\begin{array}{l}\text { Servant leadership and work } \\
\text { motivation together on OCB }\end{array}$ & $\begin{array}{l}\text { F count }(38,875)>\mathrm{F} \text { table, Sig. }<0.05 \text {, with the regression } \\
\text { equation: } \mathrm{Y}=47.497+0.026 \mathrm{X} 1+0.646 \mathrm{X} 2 \\
\text { Ho is rejected, H3 is accepted. } \\
\text { There is a significant and positive influence of servant } \\
\text { leadership and work motivation together on OCB of Generation } \\
\text { Y employees }\end{array}$ \\
\hline
\end{tabular}

The results of qualitative research in the form of conclusions on group answers and triangulation can be concluded as follows:

a. The results of qualitative research support quantitative research on the positive influence of Servant Leadership on the OCB of Generation Y employees.

b. The results of qualitative research support quantitative research on the positive influence of work motivation on the OCB of Generation Y employees.

c. The results of qualitative research support quantitative research on the positive influence of Servant Leadership and Work Motivation together on OCB of Generation Y employees.

\section{CONCLUSIONS AND SUGGESTIONS}

Based on the results of research at the quantitative and qualitative stages, it can be concluded that this study has found efforts to improve the organizational citizenship behavior (OCB) of Generation Y employees through servant leadership and work motivation, based on the following identification:

1. There is a significant and positive influence of Servant Leadership on the OCB of Generation Y employees.

2. There is a significant and positive influence on Work Motivation on OCB of Generation Y employees. 
3. There is a significant and positive influence of Servant Leadership and Work Motivation together on OCB of Generation Y employees.

Based on the above conclusions, we propose the following suggestions:

Suggestions for maintaining the indicators of Generation Y research variables can be done through training and dissemination of OCB knowledge and work motivation for all Generation Y employees, and training through training and dissemination of knowledge on servant leadership for superiors of Generation Y employees.

\section{REFERENCES}

[1] Al-Amri, M. S., Al Hajji, M. I., \& Alawaji, A. S. (2016). The Relationship between Servant Leadership and Organizational Citizenship Behavior: An Empirical Study on Saudi Insurance Companies. International Journal of Business and Management, 11(11), 264.

[2] Barbuto Jr, J. E., Gottfredson, R. K., \& Searle, T. P. (2014). An examination of emotional intelligence as an antecedent of servant leadership. Journal of Leadership \& Organizational Studies, 21(3), 315-323.

[3] Bencsik, A., \& Machova, R. (2016). Knowledge sharing problems from the viewpoint of intergeneration management. ICMLG20164th International Conferenceon Management, Leadership and Governance: ICMLG2016, 42.

[4] Chughtai, A. A. (2008). Impact of job involvement on in-role job performance and organizational citizenship behaviour. Journal of Behavioral \& Applied Management, $9(2)$.

[5] Colquitt, J., Lepine, J. A., \& Wesson, M. J. (2014). Organizational Behavior: Improving Performance and Commitment in the Workplace (4e). New York, NY, USA: McGraw-Hill.

[6] Dewayanto, Y. (2016). Motivasi Kerja, Kepuasan Kerja, Komitmen Organisasi, dan Organizational Citizenship Behaviour (OCB) (Studi Empiris pada SMK Swasta Kecamatan Gayamsari Semarang). Serat Acitya, 5(1), 23.

[7] Gibson, J. L., Ivancevich, J. M., Donnelly, J. H., \& Konopaske, R. (1991). Organizations: Behavior, structure, processes. Irwin Homewood, IL.

[8] Griffin, R. W., \& Moorhead, G. (2014). Managing People In Organization. South-Western: USA.

[9] Luthans, F. (2011). Organizational behavior: An evidence-based approach. McGraw-Hill Irwin,.

[10] Maduningtias, L. (2017). Pengaruh Kepemimpinan Transformasional Komitmen Organisasi dan Motivasi Kerja Terhadap Organizational Citizenship Behavior (OCB) Pada PT GMF Aeroasia. EDUKA : Jurnal Pendidikan, Hukum, Dan Bisnis, 02(04), 2938.

[11] Moradi, M. (2015). Modeling the relationship between work motivation and employees' organizational citizenship behaviors of y outh and sport offices in Chaharmahal and Bakhtiari province. European Journal of Physical Education and Sport, 7(1), 59-67.

[12] Musakabe, H., \& Marganingsih, T. (2004). Mencari kepemimpinan sejati di tengah krisis dan reformasi. Citra Insan Pembaru.

[13] Oren, L., Tziner, A., Nahshon, Y., \& Sharoni, G. (2013). Relations between OCBs, organizational justice, work motivation and selfefficacy. Amfiteatru Economic Journal, 15(34), 505-517.

[14] Penggalih, B., \& Zulaicha, R. (2013). pengaruh kepuasan kerja terhadap organization citizenship behavior dengan motivasi kerja sebagai variabel intervening pada karyawan PT Telkom Tegal. Performance, 16(2).

[15] Podsakoff, P. M., MacKenzie, S. B., Paine, J. B., \& Bachrach, D. G. (2000). Organizational citizenship behaviors: A critical review of the theoretical and empirical literature and suggestions for future research. Journal of Management, 26(3), 513-563.

[16] Ragil, Z., \& Solovida, G. T. (2020). Pengaruh Kepemimpinan Transformasional Dan Motivasi Terhadap Organizational Citizenship Behavior Melalui Komitmen Organisasi Sebagai Variabel Intervening. Magisma: Jurnal Ilmiah Ekonomi Dan Bisnis, 8(2), 41-50. https://doi.org/10.35829/magisma.v8i2.91

[17] Robbins, S. P., \& Judge, T. A. (2017). Organizational behavior, Edition 17, Global edition. Boston: Pearson.

[18] Robbins, S. P., \& Judge, T. A. (2019). Organizational behavior. pearson.

[19] Shaaban, S. (2018). The Impact of Motivation on Organisational Citizenship Behaviour (OCB): The Mediation Effect of Employees' Engagement. Journal of Human Resource Management, 6(2), 58-66.

[20] Spears, L. C. (2010). Character and servant leadership: Ten characteristics of effective, caring leaders. The Journal of Virtues \& Leadership, 1(1), 25-30.

[21] Sugiyono. (2013). Metode Penelitian Pendidikan Pendekatan Kuantitaif, Kualitatif, dan R\&D. In Metode Penelitian Pendidikan Pendekatan Kuantitaif, Kualitatif, dan R\&D. https://doi.org/10.1007/s13398-014-0173-7.2

[22] Vondey, M. (2010). The relationships among servant leadership, organizational citizenship behavior, person-organization fit, and organizational identification. International Journal of Leadership Studies, 6(1), 3-27. 